\title{
Field Evaluation of Different Locally Available Mounting Materials for Their Suitability under Hilly Areas of Kashmir
}

\author{
Haroon Rashid*, Gulzar Ahmad Khan, Babulal and M. K. Ghosh \\ Central Sericultural Research and Training Institute Pampore, (J\&K), India \\ *Corresponding author
}

\begin{tabular}{|l|}
\hline Key w or d s \\
$\begin{array}{l}\text { Silkworm, Bombyx mori } \\
\text { L, Evaluation, Mounting } \\
\text { materials, cocoon quality, } \\
\text { Kashmir }\end{array}$ \\
\hline Article Info \\
\hline $\begin{array}{l}\text { Accepted: } \\
\text { 17 May } 2018 \\
\text { Available Online: } \\
\text { 10 June } 2018\end{array}$ \\
\hline
\end{tabular}

A B S T R A C T
The most important device that helps or supports the silkworm larvae for comfortable spinning of cocoons is called mountage or cocoonage and the process of transfering the mature larvae on mountage is called mounting. Even if the silkworm crop is healthy, wrong mounting methods, spinning conditions and bad type of mounting material can result in inferior or poor quality cocoons and silk yarn leading to lower income to farmers. Under temperate conditions of Kashmir due to its salubrious climate, congenial or conducive for silkworm rearing still farmers lose about $20 \%$ of their cocoon crop during mounting due to use of unsuitable or faulty mounting materials. The reelibility of cocoons also gets badly affected. For identification of feasible or suitable locally available mounting material for quality cocoon production at farmers level, a comprehensive study was carried out at Lolab area of district Kupwara lying in north of Kashmir through REC Sub Unit Bandipora during the year 2015-2016, 2016-2017. During seriposition silkworms were mounted in five different types of locally available materials viz Indigofera heterantha shoots, Pinus excelsa shoot lets, Mustard hay (Brassica compestris), Mulberry shoots and Paddy grass (Oryza sativa). The results revealed qualitative improvement in cocoon as well as reeling features when Indigofera heterantha shoots fallowed by Pinus excelsa shoot lets were used for seriposition or mounting purposes for Silkworm, Bombyx mori L. Thus suggesting their feasibility for the farmers of hilly areas of Kashmir region for better economic returns and sustenance of Sericulture industry in Kashmir.

\section{Introduction}

At the end of fifth age silkworm larvae shrink in size, discharge soft light brown colored feaces and slowly stop feeding. Silk worms at this stage are called ripe worms or mature larvae and are ready to exude silk in the form of long thread for spinning of cocoons with the support of any hard object or hold fast called mountage. Thus the mountage or mounting material is the most important device that supports the silk worm larvae for spinning of cocoons comfortably (Singh, 1995, Mathur and Qadri 2010., Singh et al., 2012) and the process of transferring the mature larvae is called mounting (Rajan et al., 1996., Shinde et al., 2012). It has been observed that if the silk worm crop is healthy, wrong mounting methods, spinning conditions and bad type of mounting material can result in inferior or poor quality cocoons and silk yarn leading to lower income to farmers 
(Rajan et al., 1996, Singh and Kambli 1997, Singh et al., 2011). It has also been observed when material and structure of the mountage are not proper, the reelibility of the cocoons is reduced and other features like double cocoons, deformed cocoons and soiled cocoons get increased (Mathur and Qadri, 2010)

Various types of mountages have been used in different countries and areas like rotary mountage in Japan (Kutsumata, 1975., Rajan et al., 1996, 2000) bottle brush mountage in Brazil (Singh et al., 1994).In China many types of mountages Viz, Umbrella type, centipede type, checkerboard type are being used at farmers level. All of them are fabricated from rice straw, Wheat/paddy stray and card board material which are economical and easily available (Sugun et al., 2000)

The most common mountages used in India particularly in southern parts and West Bengal are bamboo chandrika, screen type bamboo mountage, collapsible plastic mountage and bamboo strip mountage (Singh, 1995; Rajan et al., 1996 and Haroon et al., 2001). CSR \& TIMysore have developed different types of improved mountages to replace the traditional ones and the cocoons produced out of these have improved the reeling parameters (Sangappa et al., 2010)

Under North India or North West Indian states in general and temperate climatic conditions of Kashmir in particular due to lack of adequate rearing space and rearing equipment at farmers places (Khan et al., 2010; Wani and Jaiswal 2012) farmers conduct floor rearing and shelf rearing to accommodate the huge number of silkworm larvae. On maturity they do not pick the worms, but simply keep/spread the locally available material like paddy straw, or any type of plant material over the rearing bed so as to allow the worms to crawl over the mounting material for spinning of cocoons.
But it has been seen that inspite of salubrious climatic conditions congenial for bivoltine silkworm rearing, farmers of Kashmir are loosing large quantity of cocoon crop during spinning stage due to production of defected or deformed cocoons by using unsuitable or improper mounting materials (Khan, etal2010., Malik and Khan, 2010).Thus in the present study emphasis was laid to evaluate other locally available materials in addition to those in use for their suitability at field conditions particularly for hilly areas of Kashmir valley.

\section{Materials and Methods}

The present study was carried out during the year 2015-2016 and 2016-2017 spring season at field conditions of Lolab area of Kupwara district lying in the north of Kashmir at latitude of $34^{0} 27^{\prime} 19.50 \quad$ N-longitude of $74^{0} 26^{\prime} 59.53 \mathrm{E}$ at the altitude of $1746 \mathrm{M}$ above sea level. On the seventh day of fifth age, silkworm larvae stop feeding, shrank in size, became translucent and changed their color to light yellow. Their feaces became soft which could easily be crushed with fingers. Silkworm larvae at this stage were called mature larvae. They started crawling in the rearing bed in search of suitable place to spin cocoons. For seriposition five different types of locally available plant materials Viz Indigofera heterantha shoots, Pinus excelsa shoot lets, Mustard hay (Brassica compestris), Mulberry twigs (Morus spp.) and Paddy grass (Oryza sativa) were separately arranged around the sides of rearing bed without picking the ripe larvae, by the process known as self-picking method. Small quantity of mulberry leaves was provided in the centre of the rearing bed for unripe worms (Pandey et al., 2006, 2007). The optimal temperature and relative humidity of the mounting rooms was maintained at $25^{\circ} \mathrm{C}$ and 65 to $70 \%$ throughout the period of mounting or seriposition (Jolly, 1987, Mathur and Qadri, 2010). Thus in total 
50 farmers were taken for this study, with ten farmers each with separate mounting materials. Bivoltine double hybrid $\mathrm{FC} 1 * \mathrm{FC} 2$ procured from SDD Srinagar was used as test animal. Harvesting of cocoons was done on sixth day from mounting, only after complete pupation by testing the hardening of the pupal skin (Rajan et al., 1996, Rahmathulla et al., 2007). Before harvesting of cocoons all the diseased, unspunlarvae, flimsy, Melted, thin shelled and double cocoons were removed from the mounting materials manually to prevent staining/soiling of good cocoons and counted for calculation of double and deformed cocoon \%age separately for each mounting material (Rajan et al., 1996). After harvesting of cocoons, floss covering the cocoons was removed manually. Cocoon parameters like single cocoon wt (g), single shell wt (g) and SR\% was calculated as per the procedure given by Datta in (1996). Post cocoon parameters got analyzed from SCTH Srinagar. Data on all the parameters were subjected to statistical analysis to draw logical conclusion.

\section{Results and Discussion}

\section{Assessment of cocoons harvested on different mountages or mounting materials}

From the data (table-1, fig. A) it could be seen that cocooning percentage was maximum (94.30\%) in Indigofera heterantha shoot mountages followed by Pinus excelsa shoot lets $(93.50 \%)$.It was found minimum in case of Paddy grass mounting material $(91.00 \%)$ however, statistically no significant difference was recorded among the treatments with respect to total cocooning percentage. Deformed cocoon percentage was also maximum $(10.00 \%)$ in paddy grass mounting material, followed by Mulberry shoots $(9.26 \%)$ and Mustard hay (7.30\%).Minimum deformed cocoon percentage $(5.10 \%)$ was recorded in Indigofera heterantha shoot mountage. Double cocoon percentage was recorded minimum $(4.79 \%)$ when Indigofera heterentha shoots were used as mounting material. This was followed by Pinus excelsa shoot let mounting material with 4.98\% double cocoons. Maximum double cocoon percentage $(11.85 \%)$ was recorded in Paddy grass mounting material. Statistically nonsignificant difference was observed among the different mounting materials tested as Single cocoon weight was concerned. Single shell weight and shell ratio was registered maximum $(0.365 \mathrm{~g} \& 20.88 \%)$ in Indigofera heterantha shoots followed by Pinus excelsa shoot let mounting material with $0.355 \mathrm{~g}$ and $20.06 \%$ respectively, whereas paddy grass mounting material recorded the minimum $(0.338 \mathrm{~g} \& 19.01 \%)$ single shell weight and shell ratio respectively.

\section{Test reeling results}

The reeling characters such as filament length, non-breakable filament length and reelibility percentage was analyzed and presented in table (2, fig. B). It could be observed that the cocoons harvested from Indigofera heterantha shoots and Pinus excelsa shootlet mounting materials have shown better reeling results as compared to other tested materials as they were statistically different from each other.

Maximum filament length and non-breakable filament length $(915 \mathrm{~m} \& 850 \mathrm{~m})$ was recorded in Indigofera heterantha shoots and minimum (805m\&700m) in Paddy grass mounting material. The respective filament length and non-breakable filament length were in order of $895 \mathrm{~m} \& 820 \mathrm{~m}$ in Pinus shoot lets, $837 \mathrm{~m} \& 715 \mathrm{~m}$ in Mustard hay and $814 \mathrm{~m} \& 702 \mathrm{~m}$ in Mulberry shoot mounting material respectively. Reelibility\% age (88.00\%) was recorded highest in Indigofera heterantha shoot mountage, followed by Pinus excela shootlet mountage $(86.30 \%)$. Least reelibility $(80.00 \%)$ was recorded in Paddy grass mountage. 
Table.1 Effect of different mounting materials on economic characters of Silkworm Bombyx mori L.

\begin{tabular}{|c|c|c|c|c|c|c|c|}
\hline \multirow{2}{*}{$\begin{array}{l}\text { Serial } \\
\text { no. }\end{array}$} & \multirow{2}{*}{$\begin{array}{l}\text { Treatments/ } \\
\text { Mounting } \\
\text { materials }\end{array}$} & \multicolumn{6}{|c|}{ Parameters } \\
\hline & & $\begin{array}{l}\text { Total } \\
\text { Cocooning } \\
\% \text { age }\end{array}$ & $\begin{array}{l}\text { Deformed } \\
\text { cocoon } \\
\% \text { age }\end{array}$ & $\begin{array}{c}\text { Double } \\
\text { cocoon } \\
\% \text { age }\end{array}$ & $\begin{array}{l}\text { Single } \\
\text { cocoon } \\
\text { wt }(G)\end{array}$ & $\begin{array}{l}\text { Single } \\
\text { shell wt } \\
\text { (G) }\end{array}$ & $\begin{array}{l}\text { Shell } \\
\text { ratio } \\
(\%)\end{array}$ \\
\hline 01 & $\begin{array}{l}\text { Indigofera } \\
\text { heterantha } \\
\text { Shoots }\end{array}$ & 94.30 & 5.10 & 4.79 & 1.748 & 0.365 & 20.88 \\
\hline 02 & $\begin{array}{l}\text { Pinus excela } \\
\text { Shoot lets }\end{array}$ & 93.50 & 6.20 & 4.98 & 1.770 & 0.355 & 20.06 \\
\hline 03 & $\begin{array}{l}\text { Mustard hay } \\
\text { (Brassica } \\
\text { compestris) }\end{array}$ & 93.00 & 7.30 & 6.83 & 1.760 & 0.344 & 19.54 \\
\hline 04 & $\begin{array}{l}\text { Mulberry } \\
\text { Shoots }\end{array}$ & 92.61 & 9.26 & 7.84 & 1.756 & 0.341 & 19.42 \\
\hline 05 & $\begin{array}{l}\text { Paddy grass } \\
\text { (Oryza } \\
\text { sativa) }\end{array}$ & 91.00 & 10.00 & 11.85 & 1.778 & 0.338 & 19.01 \\
\hline 06 & SE & 3.991 & 0.179 & 0.118 & 0.012 & 0.002 & 0.173 \\
\hline 07 & $\mathrm{CV}$ & 13.849 & 7.458 & 5.231 & 2.230 & 2.193 & 2.773 \\
\hline 08 & CDat5\% level & NS & 0.514 & 0.338 & NS & 0.007 & 0.499 \\
\hline
\end{tabular}

Table.2 Effect of different mounting materials on post cocoon parameters of Silkworm, Bombyx mori L.

\begin{tabular}{|l|l|l|l|l|}
\hline \multicolumn{1}{|c|}{$\begin{array}{c}\text { Serial } \\
\text { no. }\end{array}$} & \multicolumn{1}{|c|}{$\begin{array}{c}\text { Treatments/ } \\
\text { Mounting } \\
\text { materials }\end{array}$} & $\begin{array}{c}\text { Filament } \\
\text { Length (MT) }\end{array}$ & $\begin{array}{c}\text { Non Brakable } \\
\text { Filament } \\
\text { Length (MT) }\end{array}$ & $\begin{array}{c}\text { Reeli- } \\
\text { bility } \\
(\%)\end{array}$ \\
\hline $\mathbf{0 1}$ & $\begin{array}{l}\text { Indigofera } \\
\text { heterantha } \\
\text { Shoots }\end{array}$ & 915 & 850 & 88.00 \\
\hline $\mathbf{0 2}$ & $\begin{array}{l}\text { Pinus excelsa } \\
\text { Shoot lets }\end{array}$ & 895 & 820 & 86.30 \\
\hline $\mathbf{0 3}$ & $\begin{array}{l}\text { Mustard hay } \\
\text { (Brassica (compestris) }\end{array}$ & 837 & 715 & 85.85 \\
\hline $\mathbf{0 4}$ & $\begin{array}{l}\text { Mulberry Shoots } \\
\text { Paddygrass }\end{array}$ & 814 & 702 & 82.50 \\
\hline $\mathbf{0 5}$ & $\begin{array}{l}\text { sativa) } \\
\text { SE }\end{array}$ & 805 & 700 & 80.00 \\
\hline $\mathbf{0 6}$ & CV & 13.999 & 10.500 & 0.471 \\
\hline $\mathbf{0 7}$ & CD at 5\% level & 5.288 & 3.200 & 1.763 \\
\hline $\mathbf{0 8}$ & 40.314 & 35.010 & 1.358 \\
\hline
\end{tabular}


Fig. A

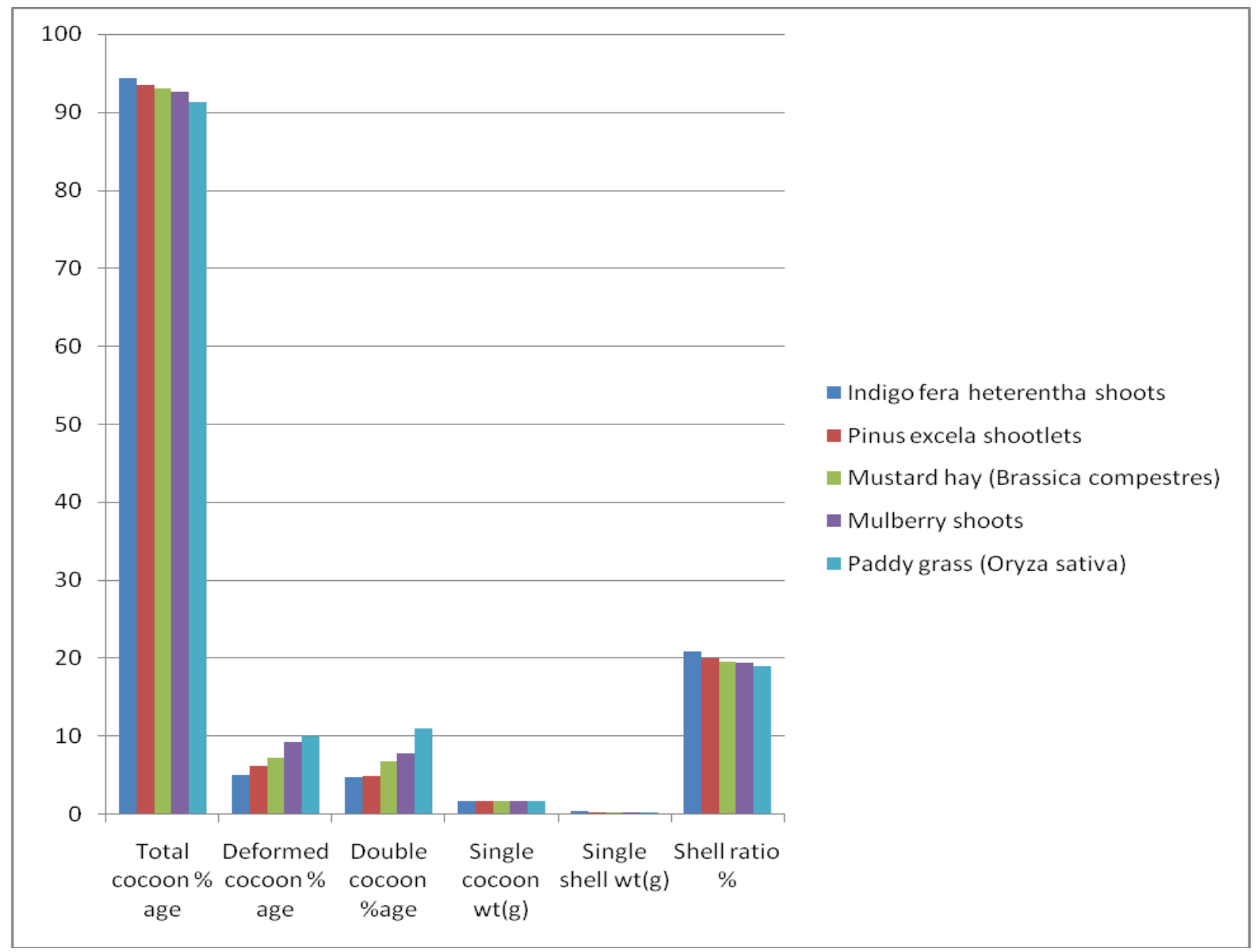

Fig. B

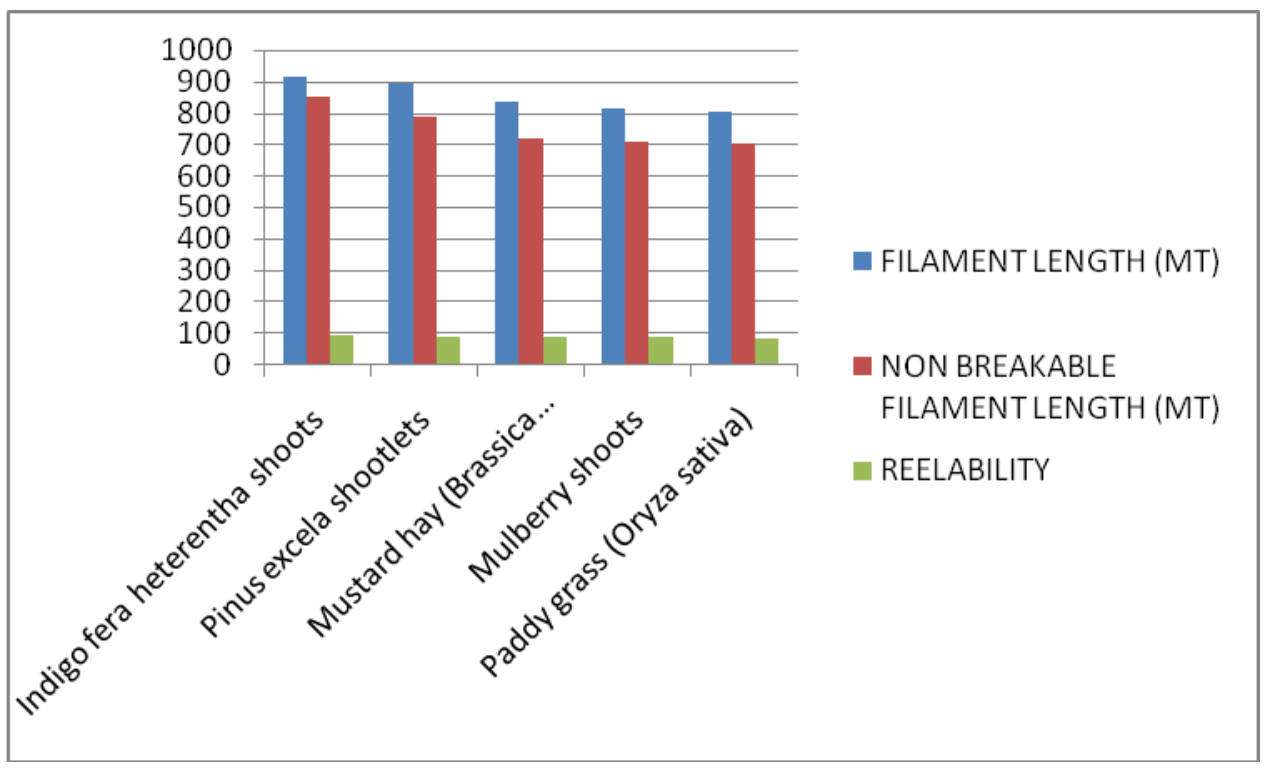


Shelf silkworm rearing at farmers place

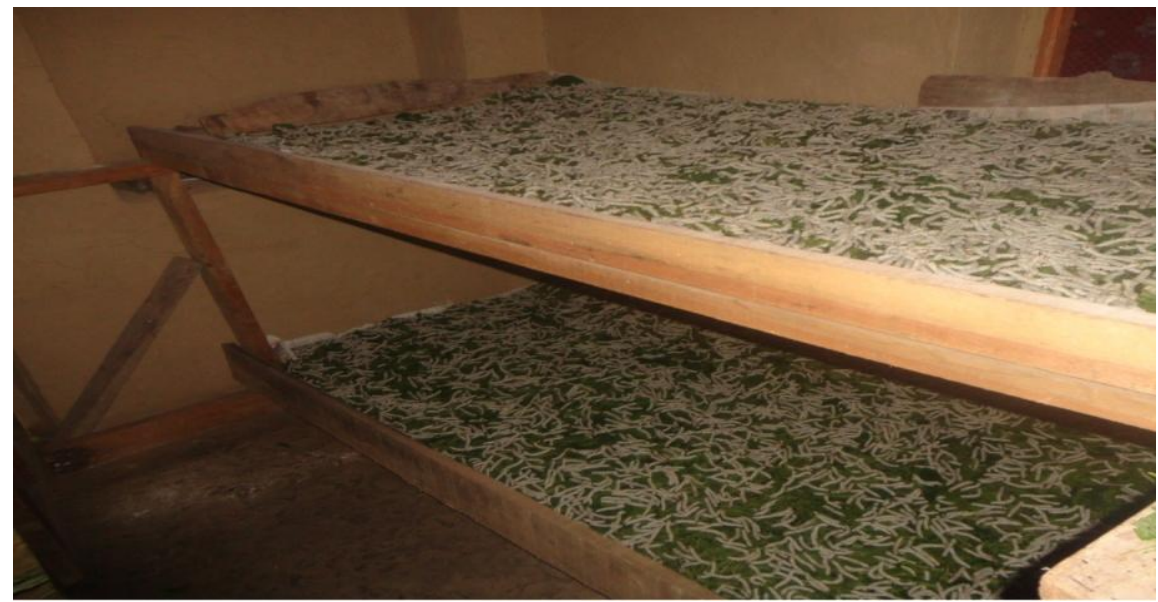

Paddy grass used as mountage/mounting material for spinning of silkworm cocoons

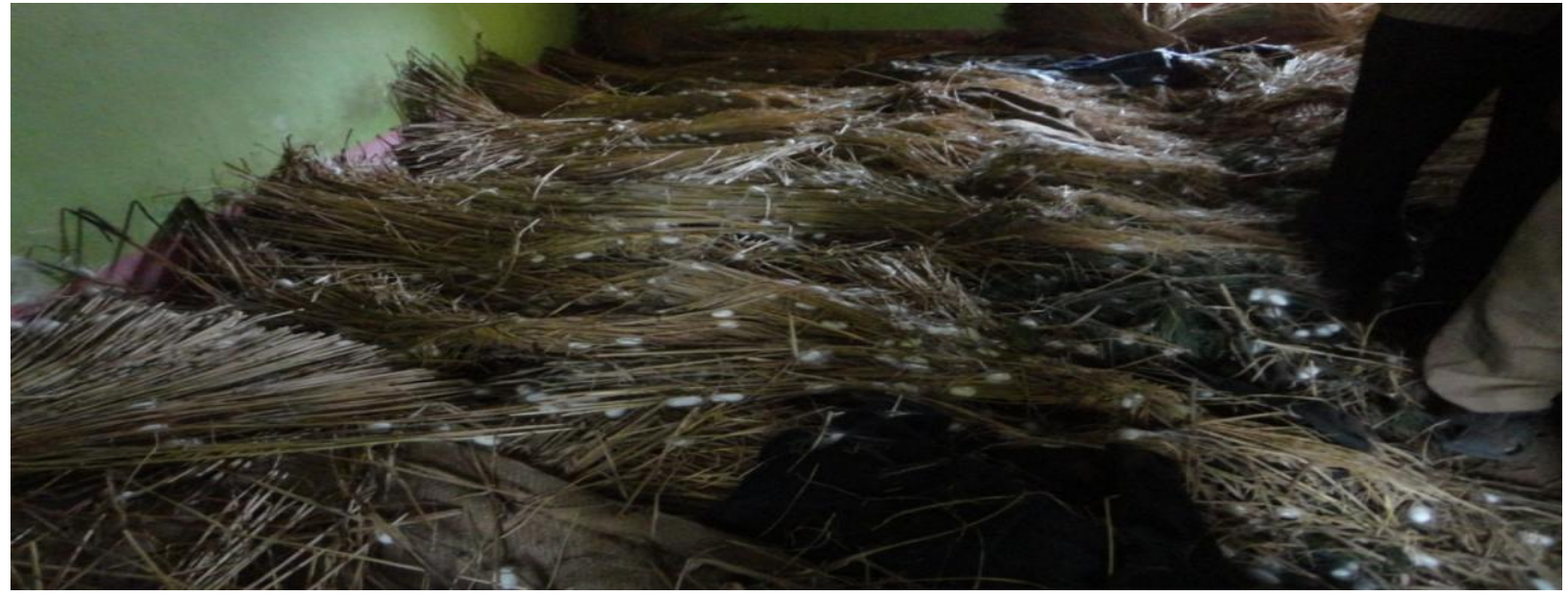

Pinus excelsa used as mounting material / mountage for spinning of silkworm cocoons at farmers place

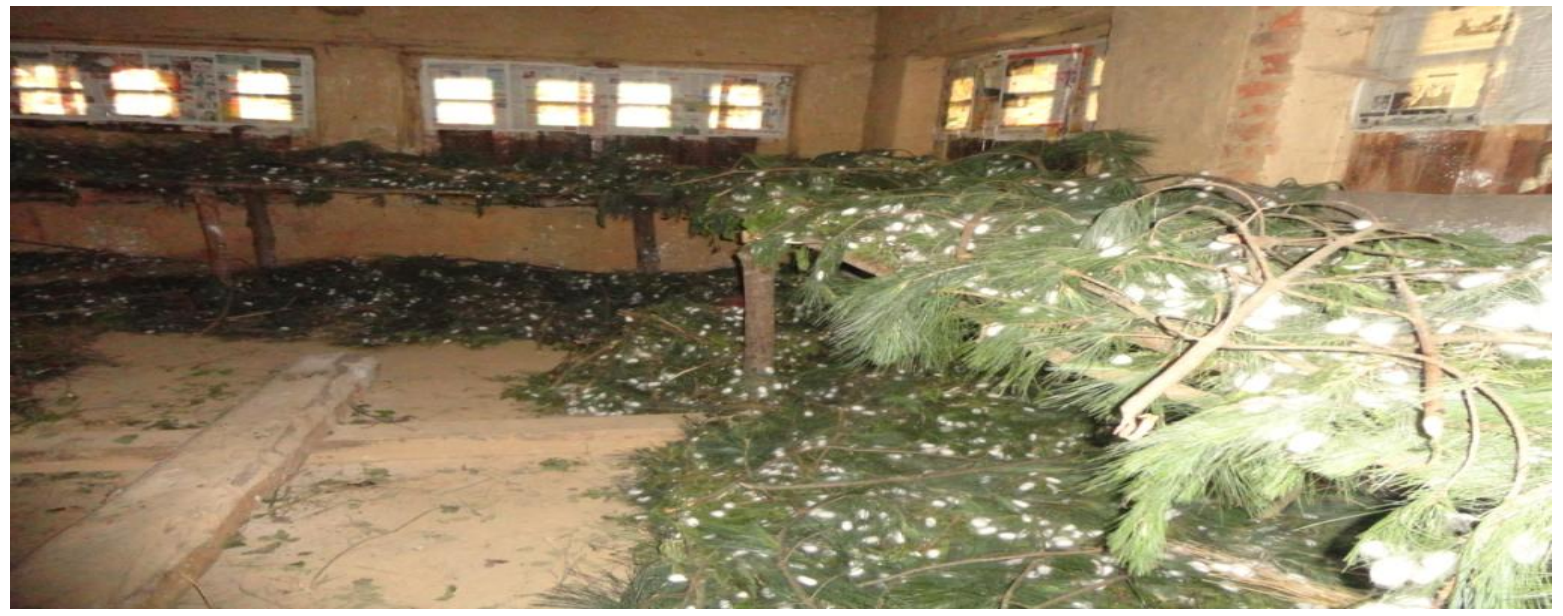


The results of the above study revealed that most of the cocoon and post cocoon parameters (reeling parameters) viz deformed cocoon percentage, double cocoon percentage, single shell weight, shell ratio, filament lenght, non-breakable filament length and reelibility were significantly superior when Indigofera heterantha shoots were used as mounting material for silkworm larvae followed by Pinus excelsa shootlet. The reasons for the superiority of these materials in improving the cocoon quality is due to the fact that these materials provide enough and suitable space for silk worms to spin cocoons comfortably. Also better passage of air current through the materials decreased the humidity of rearing bed there by improved the reeling parameters of the cocoons produced. The poor performance shown by Paddy grass and Mustard hay when used for mounting purposes is because matured larvae crawl on top or upper layer of these material for spinning of cocoons. But the upper layers did not bear the weight of huge quantity of matured larvae with the result these layers fall flat on the lower layers resulting in dumping off the material and creation of insufficient space for cocoon formation, besides increase in humidity in the bed. This has resulted in the formation of more double and deformed cocoons, besides affected post cocoon parameters. Naik and Somashekhar (2004) also observed that environmental conditions of silkworms during spinning stage had direct bearing on the post cocoon parameters.

The present findings are also in agreement with the work conducted by Tazima (1972), Periasamy and Radhakrishnan (1987), Geetha Devi et al., (1990), Rajan et al., (1996), Singh and Kamble (1997), Haroon et al., (2001), Mathur and Qadri (2010) who reported that for quality cocoon production besides other factors type of mountage, methods of mounting and mounting material used plays a paramount role. Pandey et al., (2006) advocated that in place of paddy straw which produced lot of deformed and double cocoons, semidried Eucalyptus leaves could be used successfully for mounting purposes in absence of plastic or rotary mountages. Naphade et al., (2010) also reported that Mango twigs performed better as compared to plastic mountages when used for mounting purposes.

From the studies conducted, it is inferred that Indigofera heterantha shoots followed by Pinus excela shoot lets can successfully be used as mounting materials or mountages for spinning of cocoons by silk worm larvae in hilly areas of Kashmir as they will certainly improve the cocoon production in terms of quantity and quality so that silk worm farmer can get good renumeration for their produce. These materials are also economical as both are locally available.

\section{Acknowledgements}

The authors are thankful to Smt. Zubaida Waqar (T.A), Sh. Fareed Ahmad (T.A), Sh. Mohammad Amin (T.A) and sh. Muneer Yousuf (F.A) REC cum CDC Bandipora for their help during rearing period. Our thanks are also due to Sh. Fayaz Ahmad Agha (DD) DOS Kupwara for his sensire encouragement during entire rearing period. We are also thankful to Dr. Mudasir (SC-B) CSRTI Pampore for conducting statistical analysis of the data.

\section{References}

Datta R K, Basavaraja H K and Mano Y. (1996). Manual of bivoltine rearing, race maintenance and multiplication. JICA bivoltine Sericulture technology development project, CSRTI Mysore.pp65 
Geetha Devi R G, Himantharaj M T, Vindya G S and Mathur V B. (1990). Can plastic collapsible mountage replaces the bamboo mountages. Indian Silk 10:26-28

Haroon R, Zeya S B, Khan M A and Malik M A. (2001). Effect of various mountages on the cocoon characters of Bombyx mori $\mathrm{L}$ in temperate climatic conditions of Kashmir valley. Oriental Science 6 (2):113-118.

Jolly M S (1987). Appropriate sericulture technique. Ed: M.S. Jolly. International Centre for Tropical Research and Training in Sericulture Mysore India. pp.75

Khan M A, Dhar A and Mir N A (2010).Constraints and strategies for multiple cocoon crops in J\&K State. In: Proceedings of work shop on multiple cocoon crops for sustainable sericulture in J\&K state held at SKICC Srinagar on October 18, p4-8.

Kutsumata F (1975). Silk worm mounting. In: Text book of tropical sericulture (111adn). Japanese overseas cooperation volunters, Tokyo Japan, pp.503-519.

Malik F and Khan M A (2010). The problems and prospects of multiple cocoon crops in Jammu and Kashmir. In: Proceedings of work shop on multiple cocoon crops for sustainable sericulture in $\mathrm{J} \& \mathrm{~K}$ state held at SKICC Srinagar on October 18, p9-16.

Mathur V B and Qadri S M H. (2010). Manual on mountages, mounting and harvesting technology for quality cocoon production. A publication of CSR\&TI Mysore. Central Silk Board. Ministry of Textiles. Govt. of India. Nandikeswara printing press new Sayyaji Roa road, Mysore. pp23

Naik, S V and Somashekhar T H (2004). Influence of cocoon spinning condition on reeling performance and quality of raw silk of multivoltine cocoons. Indian Journal of fibre and Textile Research. 29: 324-332.

Naphade S T, Hiware C J and Avhad S B (2010). Development of improved mountage using mango plant twigs during lack of suffient number or absence of mountages on field for silkworm cocoons. Recent Research in Science and Technology, 2 (7): 5-8

Panday R k, Khan M A, Bindroo, B B, Dhar A and Chauhan S S. (2007). Plant shoot mountages of north-western India. Researchgate, 46, 4-5

Pandey R k, Khan M A, Dhar A and Chauhan S S. (2006). Performance of different locally available plant materials for mounting of silkworms. In: Proceedings of regional seminar on Prospects and problems of sericulture as an economic enterprise in North West India. Nov.11\&12 p.190-193

Periasamy K and Radha Krishnan S (1987). Design of a new type of mountage and assessment of its advantages over the conventional bamboo mountage. Sericologia, 17 (1): 35-44.

Rahmathulla V K, Das P, Ramesh M, and Rajan R K. (2007). Growth rate pattern and economic triats of Silkworm, Bombyx mori L under the influence of folic acid administration. J.Appl.Sci.Environ.Manage. 11 (4):8184

Rajan R K, Himantha Raj M T and Singh G B. (2000). Rotary mountage and its advantages. Indian Silk 39 (4): 4-6.

Rajan R K, Tamio Inokuchi and Datta R K. (1996). Manual on mounting and harvesting technology. JICA bivoltine sericulture technology development Project, CSR \& TI Mysore. Printed at Jawalamukhi Job press 4411.R.K Road, Basava angdi Bangalore, pp.22

Sangappa S, Bhanuprakash R, Srinivasa G and Dandin S B. (2010). Impact of 
different types of mountages on raw silk production and quality. Nippon Silk Gakkaishi 18:15-19

Shinde K S, Avhad S B, Jamdar S V and Hiware C J. (2012). Comparative studies on the performance of mountages on cocoon quality of Bombyx mori L. Trends in life Science.1 (4): 8-11

Singh G B and Kamble C K (1997). A review of silkworm spinning. Bull.Sericult.Res 8: 71-75.

Singh G B, Chandrakanth K S, Vijayakumari K M and Qadri S M H (2012). Impact of mountages in seasons on cocoon yield and reeling parametres of bivoltine silkworm. Bombyx mori. Green farming, 3 (1):69-73

Singh G B, Rajan R K, Inokuchi T, Himantha Raj M T, Menal A and Datta R K (1994). Studies on use of plastic bottle brush mountage for silkworm mounting and its effect on cocoon characters and reebility. Indian Journal of Sericulture. 33 (1): 95-97

Singh G B. (1995).Silkworm mountages. Indian Silk 4 (1):13-16

SinghG B, Chandrakanth K S, Kirsur M V and Qadri S M H (2011) Mounting, mountages, mounting care and cocoon harvesting-a review-Indian Journal of Sericulture, 50 (1)1-8

Sugun R, Chandra Kalla M V and Katti S R. (2000). Types of mountages practiced in Chinese sericulture. Bull.In.Acad.Seri. 4 (1): $82-84$

Tazima Y (1972). Hand book of silkworm rearing. Translated by Central Silk Board in 1997.

Wani, K A and Jaiswal, Y K (2011).Health hazards of rearing silk worms and environmental impact, assessment of rearing households of Kashmir, India. Nature Environment and Polution Technology, 10 (1): 85-90.

\section{How to cite this article:}

Haroon Rashid, Gulzar Ahmad Khan, Babulal and Ghosh M. K. 2018. Field Evaluation of Different Locally Available Mounting Materials for Their Suitability under Hilly Areas of Kashmir. Int.J.Curr.Microbiol.App.Sci. 7(06): 1597-1605. doi: https://doi.org/10.20546/ijcmas.2018.706.191 